\title{
Results, Reflection and Trends on the EU27 and Portuguese Policy in Renewable Energy
}

\author{
Nuno Domingues, Ricardo Raimundo \\ ISEC ISEL, Instituto Superior de Educação e Ciências, Instituto Superior de Engenharia de Lisboa, Lisbon, Portugal \\ Email: nndomingues@gmail.com
}

How to cite this paper: Domingues, N., \& Raimundo, R. (2020). Results, Reflection and Trends on the EU27 and Portuguese Policy in Renewable Energy. Modern Economy, 11, 2145-2155.

https://doi.org/10.4236/me.2020.1112141

Received: October 5, 2020

Accepted: December 28, 2020

Published: December 31, 2020

Copyright $\odot 2020$ by author(s) and Scientific Research Publishing Inc. This work is licensed under the Creative Commons Attribution International License (CC BY 4.0).

http://creativecommons.org/licenses/by/4.0/

\begin{abstract}
Decentralized distributed power generation and energy production (simplified as Decentralized production) has been playing an increasingly important role in the consumption - production, energy relationship, as well as the promotion of renewable energies and even in changing consumption habits. To achieve the objective of sustainable development, microgeneration has an essential contribution to its achievement, and any support for this initiative is understood as a good investment for the future. The present paper reflects on the electricity generation market in Europe EU-27 and in Portugal, namely from where does import energy, what taxes and how dependent are. Under an economical perspective, the present paper proposes mechanisms to promote decentralized production effectively. Also, the present paper establishes the advantages of decentralized electricity generation over centralized generation, based on the EU-27 data and on comparisons. It is possible to conclude that the share of renewable energies in the mix is starting to really be high and is getting an important role, despite the availability of fossil fuels and the implemented energy system to supply the fossil fuels. It is recommended that traditional fossil fuels big power plants be phased out progressively ASAP. Carbon Capture and Sequestration is an alternative during this period, turning them to low-carbon plants. However, decentralized production is more effective in environmental and economic vectors. At a system level, security of supply and flexibility of renewable energies are more guaranteed in decentralized production.
\end{abstract}

\section{Keywords}

Renewable Energy, Decentralized Generation, Market Incentives, Strategy, Energy Business 


\section{Introduction}

For its own consumption, the EU needs energy which is imported from third countries. In 2018, the main imported energy product was petroleum products (including crude oil, which is the main component), accounting for almost two thirds of energy imports into the European Union (EU), followed by gas (24\%) and solid fossil fuels (8\%).

Figure 1, Figure 2 and Figure 3 (European Commission Statistics, Eurostat 2019a, 2019b) present the EU imports for crude oil, solid fuel and natural gas.

It is possible to realize that Russia is the main EU supplier of crude oil, natural gas and solid fossil fuels, followed by Norway for crude oil and natural gas.

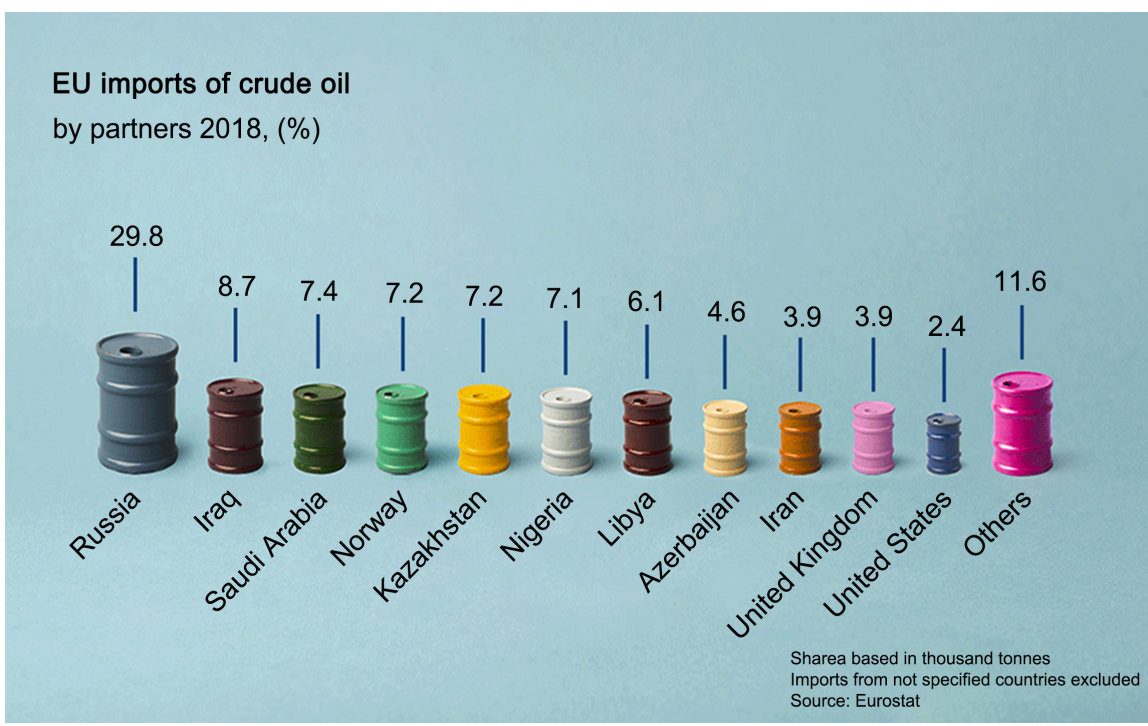

Figure 1. EU-27 imports of crude oil.

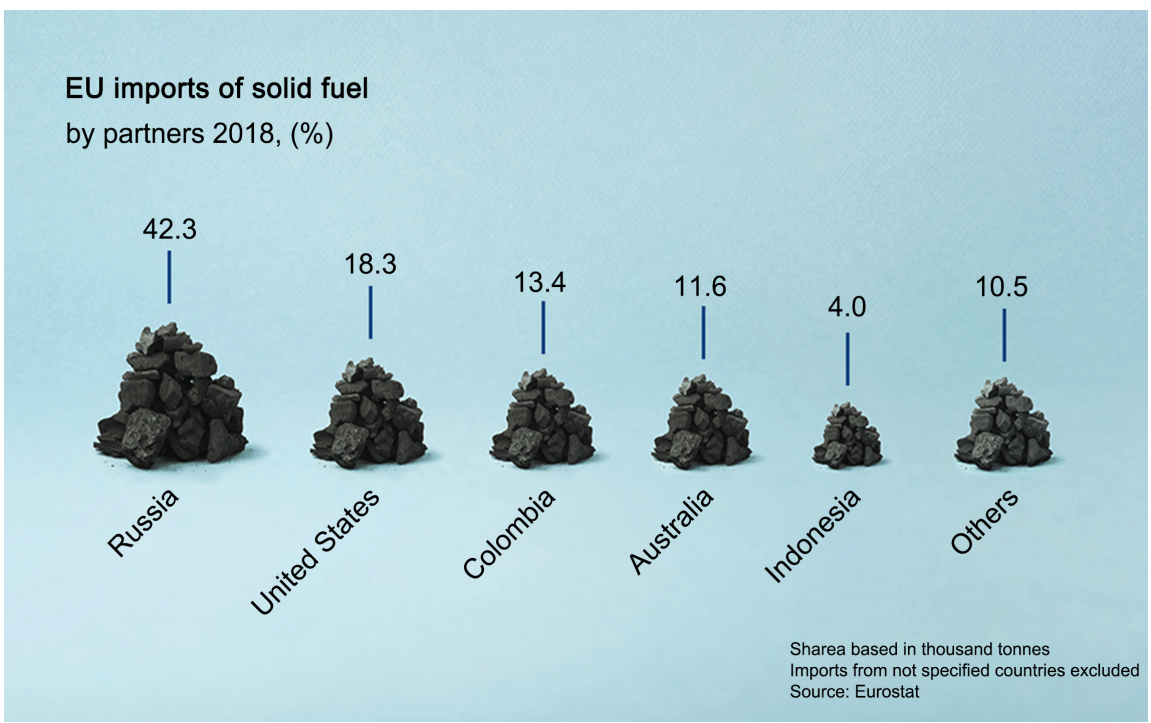

Figure 2. EU-27 imports of solid fuel. 
EU imports of natural gas

by partners 2018 , (\%)

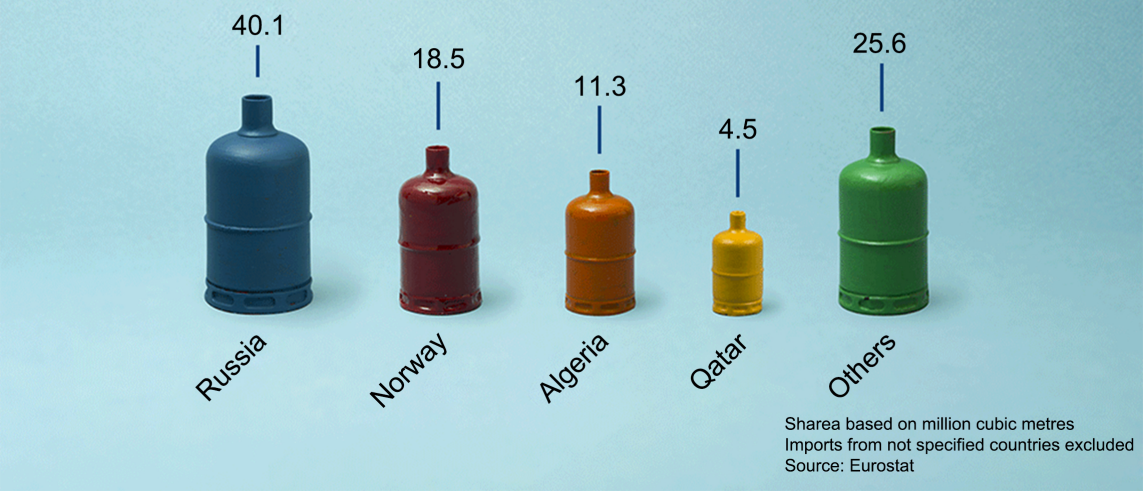

Figure 3. EU-27 imports of natural gas.

The stability of the EU's energy supply may be threatened if a high proportion of imports are concentrated among relatively few external partners. In 2018, almost two thirds of the extra-EU's crude oil imports came from Russia (30\%), Iraq (9\%) and Saudi Arabia, Norway, Kazakhstan and Nigeria (7\% each). A similar analysis shows that almost three quarters of the EU's imports of natural gas came from Russia (40\%), Norway (18\%) and Algeria (11\%), while almost three quarters of solid fuel (mostly coal) imports originated from Russia (42\%), the United States (18\%) and Colombia (13\%). More than $80 \%$ of energy imports are petroleum products in Cyprus, Malta, Greece, Sweden and Romania and more than a third is gas in Hungary, Austria and Italy. Around 20\% of energy imports are solid fuels in Slovakia and Poland.

Figure 4 presents the EU Energy dependency ratio. European Commission Statistics, Eurostat (2019a, 2019b).

The dependency rate shows the extent to which an economy relies upon imports to meet its energy needs. It is measured by the share of net imports (imports - exports) in gross inland energy consumption (meaning the sum of energy produced and net imports). In the EU in 2018, the dependency rate was equal to $58 \%$, which means that more than half of the EU's energy needs were met by net imports. This rate ranges from over $90 \%$ in Malta, Luxembourg and Cyprus to below 25\% in Romania, Denmark and Estonia. The dependency rate on energy imports has increased since 2000, when it was just 56\%. European Commission Statistics, Eurostat (2019a, 2019b)

The energy market in Portugal generates tens of billions of euros annually and is also responsible for the largest share of the trade deficit. According to DGEG (2019a, 2019b) the weight of the import of energy products in the FOB goods balance was $15.2 \%$ in 2019. The value in terms of percentage of the Gross Domestic Product (GDP) was 3.2\%, close to the values affected by health and education (DGEG, 2019a, 2019b) (European Commission, 2019) (European Commission Statistics, Eurostat, 2019a, 2019b). From 2010 to 2018, Portugal's energy dependence 
decreased, as can be seen in Figure 4, being a good factor for security of supply.

Regarding electricity generation, the total net electricity generation in the EU was 2806 TWh in 2018, which was similar to the year before, following an increasing trend, as shown in Figure 5 European Commission Statistics, Eurostat (2019a, 2019b).

The level of net electricity generation in the EU in 2018 was 1.3\% lower than its relative peak of 2008, when total output stood at 2844 TWh.

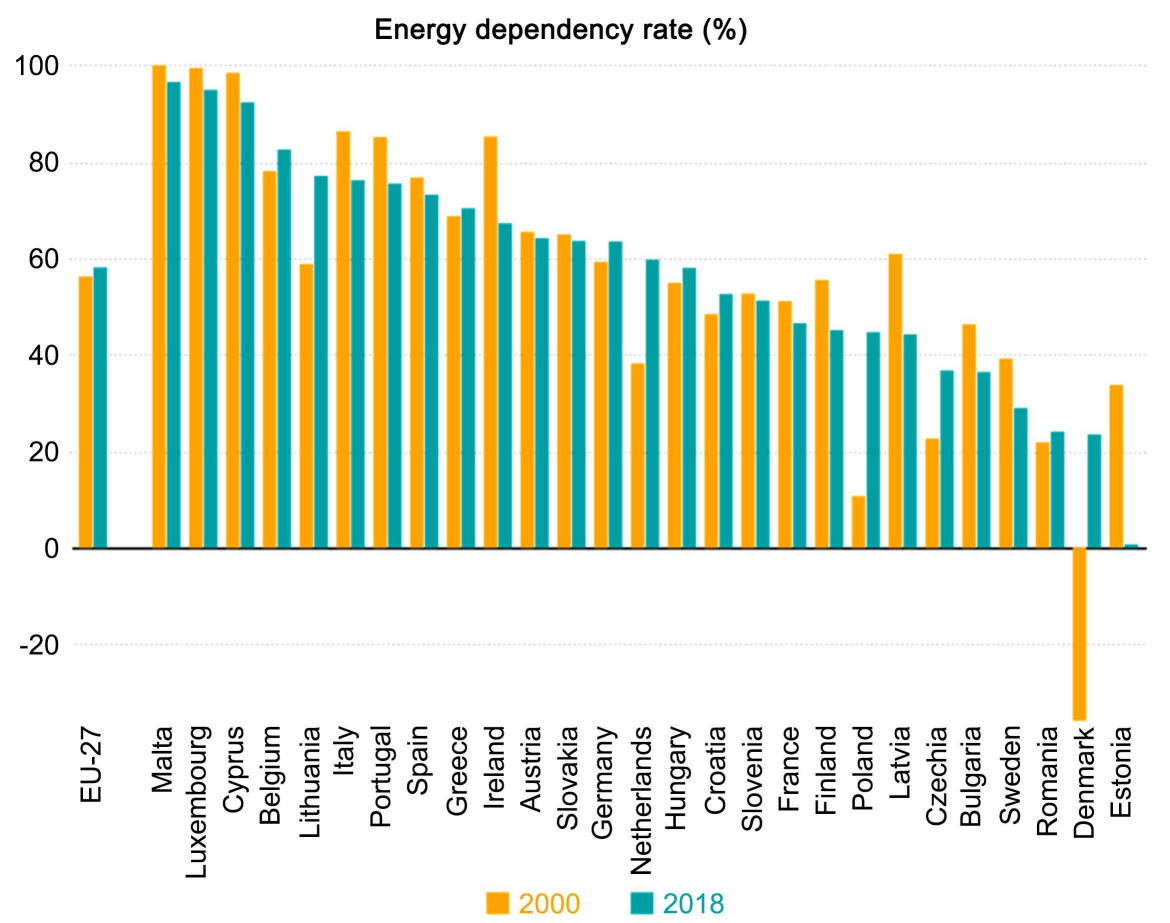

Figure 4. EU-27 Energy dependency ratio.

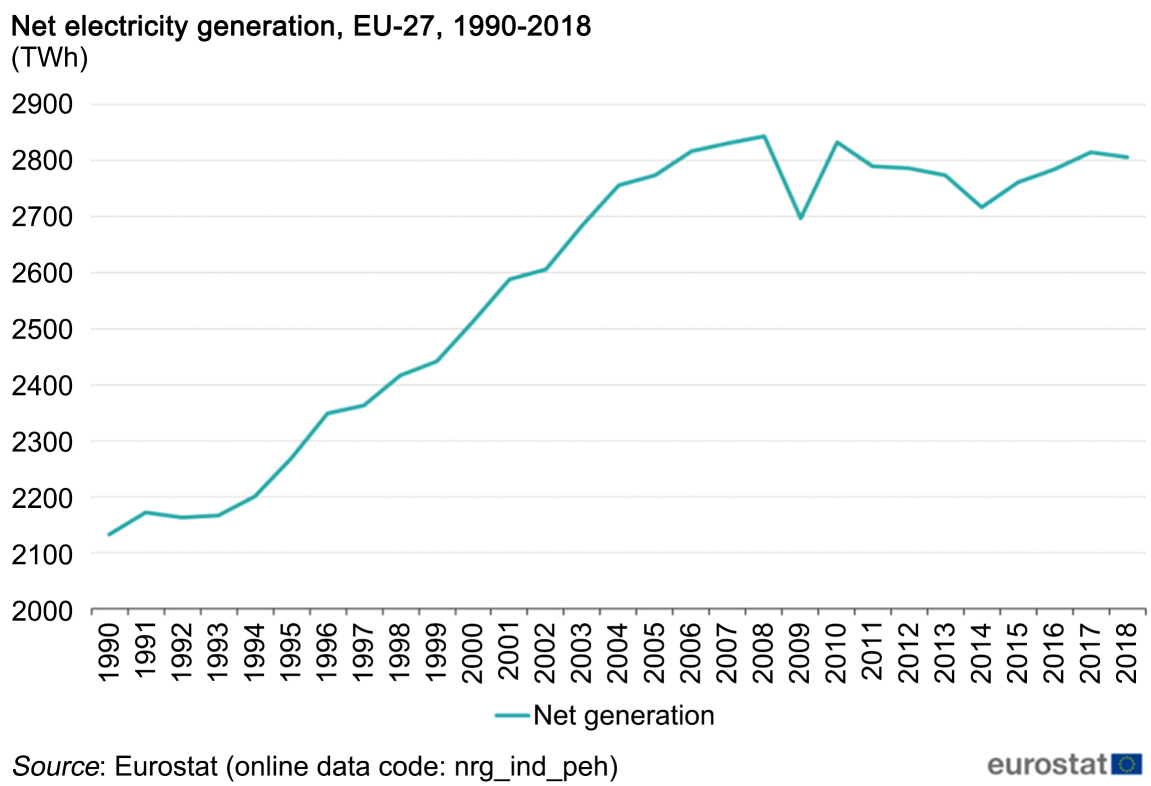

Figure 5. EU-27 Net electricity generation. 
Figure 6 presents the overall change in net electricity generation, 2008-2018 for EU-27 and their Member States. Germany had the highest level of net electricity generation in 2018 among the EU Member States, accounting for $21.7 \%$ of the EU total, just ahead of France (19.9\%); Italy (10.0\%) was the only other Member State with a double-digit share. During the period covering 2008 to 2018, there was an overall reduction of $1.3 \%$ in the level of EU net electricity generation, as it can be seen in Figure 5. This pattern was repeated in 11 of the 27 EU Member States. The largest overall contractions were registered in Lithuania $(-74.1 \%)$, Luxembourg $(-38.3 \%)$ and Hungary $(-20.2 \%)$, while there were also double-digit reductions in Denmark, Greece, Spain, Malta and Belgium. By contrast, among the $16 \mathrm{EU}$ Member States where there was a higher level of electricity generation in 2018 (compared with 2008), double-digit increases were recorded in Portugal, Latvia and Estonia. Between 2017 and 2018, the largest annual increases in electricity generation were recorded for Malta (19.3\%) and Croatia (14.4\%). At the other end of the scale, there were 15 EU Member States which reported a fall in their level of electricity generation in 2018, with the largest reductions in Lithuania (-17.1\%), Belgium (-13.4\%) and Latvia (-11.7\%). European Commission Statistics, Eurostat (2019a, 2019b)

Figure 7 (PortáteisnaHora, 2019) presents the net electricity generation for EU-27 for the year 2018. Close to half (45.5\%) of the net electricity generated in the EU in 2018 came from combustible fuels (such as natural gas, coal and oil), while a quarter (25.8\%) came from nuclear power stations. Among the renewable energy sources shown in Figure 3, the highest share of net electricity generation in 2018 was from hydropower plants (13.0\%), followed by wind turbines (11.3\%) and solar power (4.1\%).

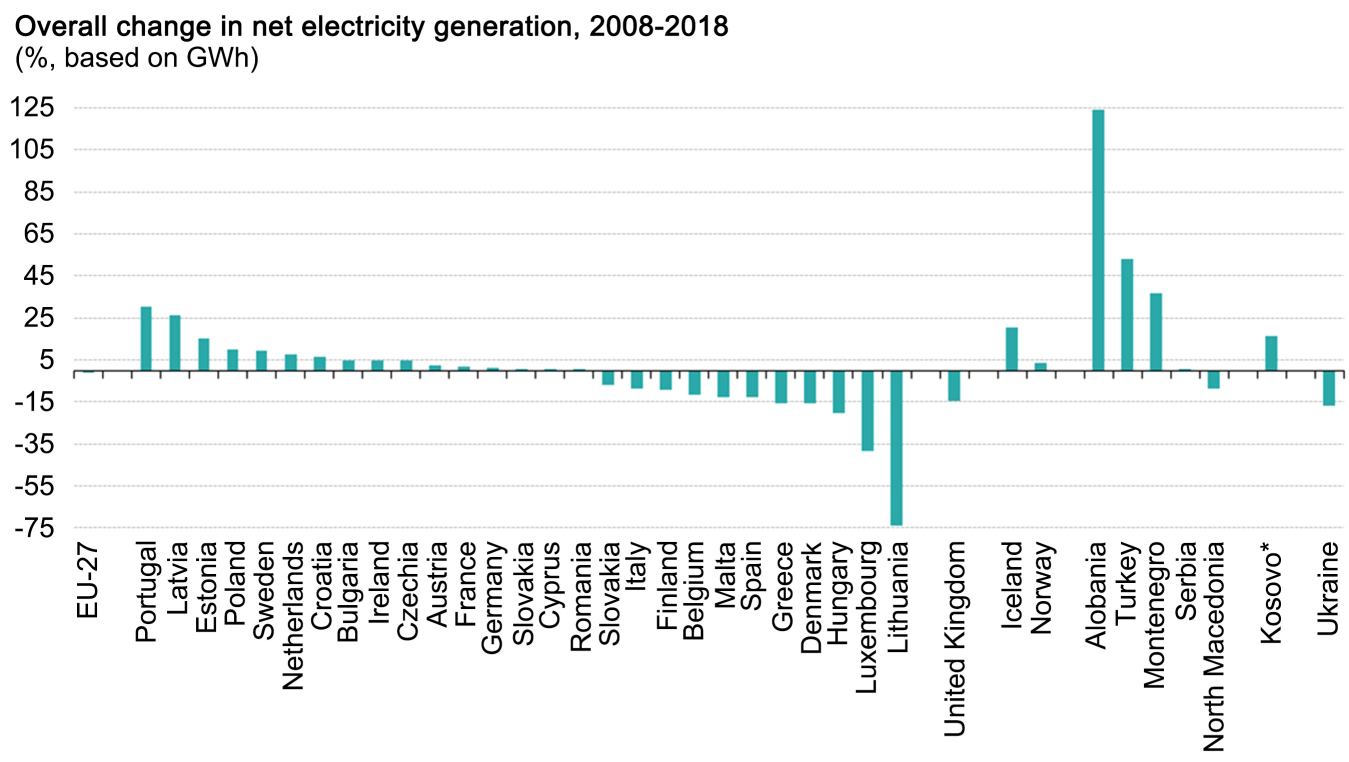

*This designation is without prejudice to positions on status, and is in line with UNSCT $1244 / 1999$ and the ICJ Opinion on the Kosovo Declaration of Independence. Source: Eurostat (online data code: nrg_ind_peh)

Figure 6. EU-27 and their Member States overall change in net electricity generation from 2008 to 2018. 
Electricity production by soource, EU-27, 2019

(\%)

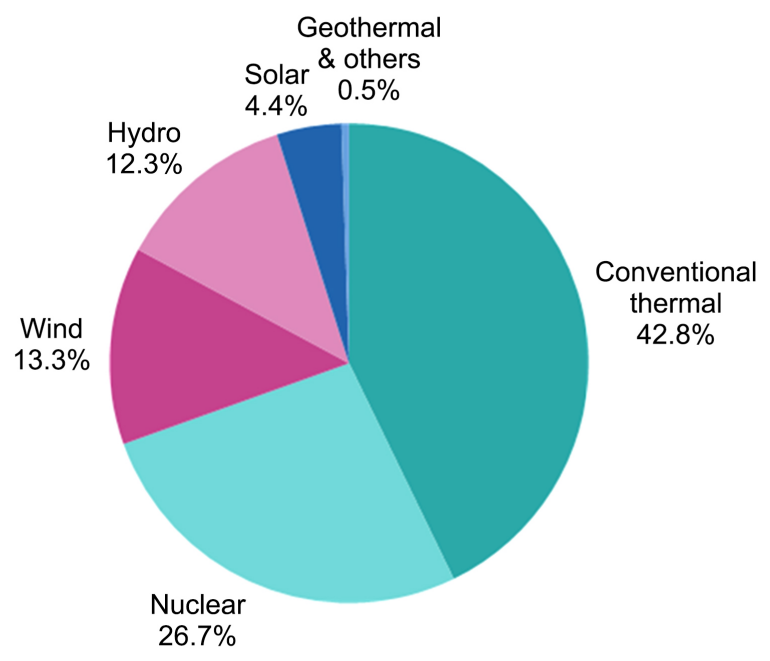

Source: Eurostat (online data code: nrg_cb_pem)

eurostat?

Figure 7. EU-27 net electricity generation for the year 2018.

The relative significance of renewable energy sources in relation to EU net electricity generation grew between 2008 and 2018 from $16.6 \%$ to $28.5 \%$, while there was a relatively large decrease in the significance of combustible fuels from $53.6 \%$ to $45.5 \%$ and also a reduction in the share of electricity generated from nuclear power plants from $29.6 \%$ to $25.8 \%$. Among the renewable energy sources, the proportion of net electricity generated from solar and wind increased greatly: from $0.3 \%$ in 2008 to $4.1 \%$ in 2018 for solar power and from $3.9 \%$ in 2008 to $11.3 \%$ in 2018 for wind turbines (PortáteisnaHora, 2019).

During the 10-year period from 2008 to 2018, the consumption of electricity by households rose in the EU by $1.3 \%$, as is shown in Figure 8 (PortáteisnaHora, 2019). These figures on overall household electricity consumption are likely to be influenced, in part, by the average number of persons living in each household and by the total number of households, both of which are linked to demographic events. Other influences include the extent of ownership and use of electrical household appliances and consumer goods as well as the use of energy saving devices.

Electricity consumption by households rose at a much faster rate than the EU average between 2008 and 2018 in Romania (where the overall growth was $22.9 \%$ ), while an increase of $19.9 \%$ was recorded for Luxembourg and a rise of $17.1 \%$ in Malta. At the other end of the scale, household electricity consumption fell in 10 of the EU Member States, generally by less than $20 \%$. Among these ten Member States with decreases in electricity consumption, the largest reductions were recorded in Latvia (17.8\%), Germany (8.1\%) and Belgium (7.7\%) (PortáteisnaHora, 2019). 
Final energy consumption in households per capita, by country, 2013 and 2018 ( $\mathrm{kg}$ of oil equivalent)

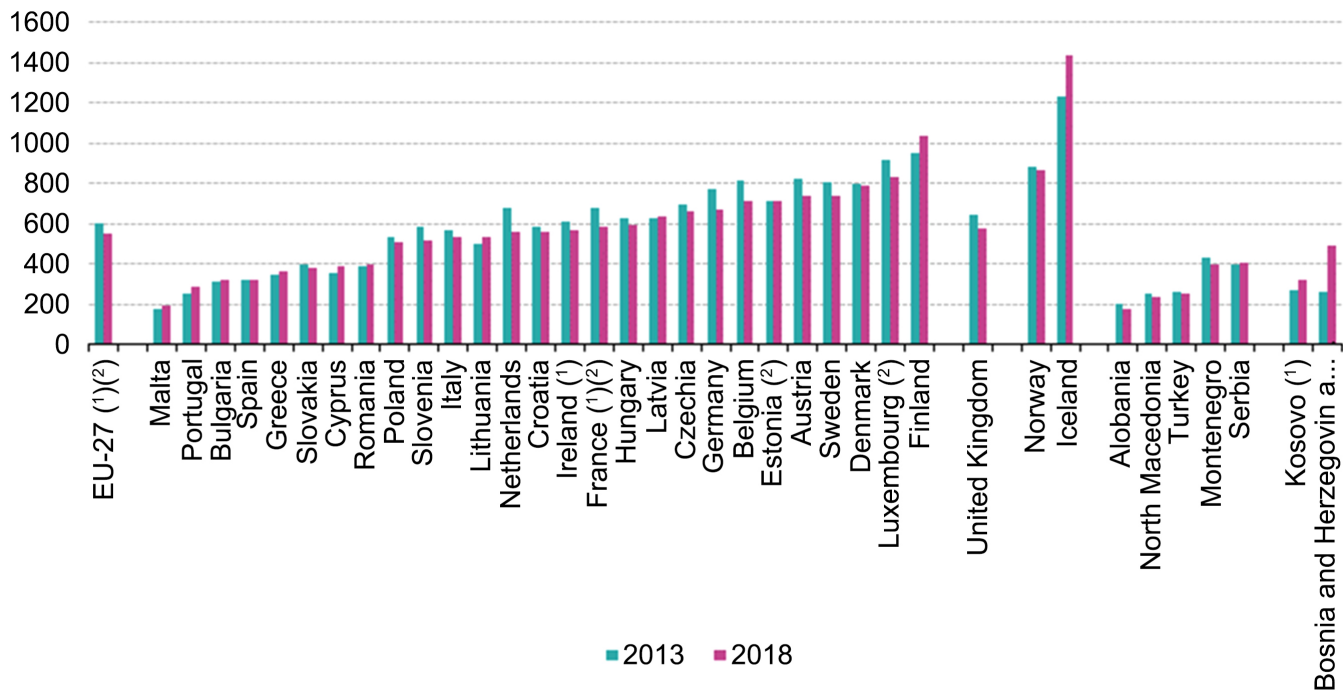

Source: Eurostat (online data code: sdg_07_20)

(1) 2018 data are estimated and/or provisional.

${ }^{2}$ ) Break(s) in time series between the two years shown.

(3) 2014 data (instead of 2013).

eurostat?

Figure 8. EU-27 and their Member States consumption of electricity by households from 2008 to 2018.

\section{Decentralized Production: The First Results in Portugal}

Decree-Law n ${ }^{\circ} 363 / 2007$, of 2 November, defines the scope of the Group I units, which use renewable sources such as Solar, Wind, Water, Biomass Cogeneration (as long as integrated in the building's heating) and batteries, fuel (based on hydrogen from renewable micro-production). It also applies to Group I units if they use non-renewable sources in cogeneration as primary energy (natural gas boiler equipped with a "Stirling engine" coupled to a microgenerator).

The Conditions of Access to the activity say that any entity that has a contract for the purchase of electricity in BT in a given location may, in that same location, be a micro producer. The LV Distribution Network Operator and the Last Resort Supplier have a fundamental role in this whole process, exercising a public service relevant to the good licensing result of the Micro production Units. The conditions for access to activities must follow certain rules while the power of the production installation at the reception point is limited to $50 \%$ of the controlled power, with $5.75 \mathrm{KW}$ in the general regime and $3.68 \mathrm{KW}$ in the subsidized regime, as a maximum value of connection power. The $50 \%$ limit is not applicable to condominiums; however the maximum values are maintained regardless of the value of the controlled power. There is a technical limit for the sum of the power registered to each PT and access to the micro production activity is subject to registration in the Maintenance Registration System (SRM).

The producer has the main right to sell all the energy produced by the power allowed to the RESP, as well as the connection preceded by the issuance of the 
exploration certificate and the producer has to consume all the heat produced in the case of cogeneration and deliver the energy to the RESP in a way not to cause disturbance.

The Remuneration Regimes were as follows: In General Regime it is applicable to all producers that have access to the activity (power connection up to 5.75 $\mathrm{KW})$; In a subsidized regime, it is applicable to all producers with a connection power up to $3.68 \mathrm{KW}$ that use the following renewable sources, Solar, Hydro, Biomass Cogeneration, Fuel Cells or combinations of the previous renewable sources. Tax benefits are granted on VAT, IRS and IRC. VAT is applied at a rate of $12 \%$ (for the Mainland) to devices intended for the capture and use of Solar, Wind and Geothermal energy, as well as other alternative forms of energy and also the production of energy from waste. For the IRS, $30 \%$ of the amounts spent on the acquisition of new equipment are deducted from the collection, with a limit of $777 €$ for the use of renewable energy, the production of electricity and cogeneration by natural gas microturbines. Income of less than $€ 5000$ resulting from the micro production activity is excluded from IRS taxation. The IRC has a minimum useful life of 4 years, for solar energy equipment, for the purposes of reintegration and amortization of the investment, this measure allows a reduction of the annual IRC accumulated with other incentives (WTO, 2019a, 2019b).

\section{The Financial Crisis of 2011 and Its Impact on the Electricity Sector}

Alerted by the magnitude of the deficit in Portugal in May, and by the bankruptcy of Irish banks, international investors began to take a closer look at the finances of EU member states and Portugal was considered a risk due to its weak economic growth and high level of debt. It has borrowed huge amounts to finance sacred welfare entitlements and private spending, while protecting jobs through outdated labour laws that make it difficult to hire and fire workers. Its industry has also broadly failed to move with the times. Interest rates were driving Portugal into the situation already experienced in Greece and Ireland. While investors feared that Portugal would not be able to meet its debt obligations and may need help, the Portuguese State insisted on the adequacy of its debt reduction plan and its lack of need for financial assistance. Public debt was $86 \%$ of GDP, revealing a huge weight in the economy, current State expenditure (without interest) increased from $26.7 \%$ in 1990 to over $40 \%$ of GDP in 2010 and household indebtedness was due years of high levels of consumption not compatible with earned income.

Portugal ended 2010 with a controversy between renewable and classic forms of energy production, after a petition from a consumer protection association states that $6.5 \%$ of the costs of general economic interest (CIEG) in the electricity tariff were due to renewable sources. Although this petition confused issues, which was poorly structured and poorly reasoned, it had significant support from the population and was discussed in Parliament. On this issue, stakehold- 
ers in the renewable energy sector claimed that the proposal would create direct jobs, invest locally, and R \& D financing of new technologies in the energy sector. In addition, they have a deduction of $2.5 \%$ of the income from income rights paid to the municipalities and must pay for the transport infrastructure. In return, traditional energy producers should only apply for a license and, if there is capacity for energy injection, they should only pay administrative costs and nothing else immediately outside the plant.

Internationally, the challenges of the energy sector were full of uncertainty: the financial crisis, China, the end of conventional oil, Kyoto and Cancún, the cost of renewable energy and efficiency. At the end of 2010, Europe suffered from difficulties in three dimensions: security of energy supply (Europe has a very high rate of external energy, exceeding $50 \%$, which is expected, perhaps, to exceed $65 \%$ within 20 years), environment (Europe has made important environmental commitments that have led to important targets imposed on its member states) and competitiveness (devastated by the severe economic and financial crisis, Europe sees its growth threatened by stagnant business investment and household consumption).

\section{Available Instruments to Boost Decentralized Generation}

What characterizes, in economic terms, a subsidy, is not the existence of a financial transfer, but a reduction in costs, for consumers or producers, in relation to what would be expected. Thus defined, the range of grants expands much more and includes interventions such as:

- Financial contributions-these contributions include all payments for goods and services included in the State Budget and which normally correspond to an incentive for a specific activity;

- Tax reductions and exemptions-are a recurring type of subsidy. The State decides to grant tax benefits, either to investments or to expenses that, in some way, it considers beneficial to society;

- Use of infrastructure below cost price-the State builds infrastructure for which it does not receive compensation. If expropriation occurs at prices below market prices, the State can build a more profitable infrastructure;

- State guarantees and guarantees-the State's practice of granting bank guarantees and guarantees to public (and private) businesses that it considers to be in the public interest. In all cases where financial participation by the State is required, a subsidy is implied, because the State has a credit risk profile that lowers the cost of capital for these projects. The State gives up its credibility, even when the project is entirely private. Without counterparts, the State is effectively exposed to risk, even if there is no visible financial transaction.

The arguments for the existence of subsidies are immense, almost as many as the political objectives that a State pursues. For example, subsidies in the energy field can aim at energy independence, protection of the environment, diversifi- 
cation of energy sources, technological innovation, research and development, access to energy to meet basic needs. For all these objectives, there are political instruments that correspond in one way or another to subsidies, in the broad definition that one (WTO, 2019a, 2019b); (OECD, 2019); (Earth Track, 2019a, 2019b); (Unfair Aid, 2005); (European Environment Agency, Copenhagen, 2004); (US Department of Commerce, 2019); (The Earth Council, 2019); (International Institute of Economics, 2019); (Fiscally Green Canada, 2019); (Earth Track, 2019a, 2019b).

\section{Methodology for Reflection on the Decentralized Generation Role}

This study relies mostly on non-empirical research, in which the researchers adopted both inductive and deductive reasoning to theorize logical assumptions about the decentralized generation role. Building on reflection and personal observation on the field, the researchers carried out this piece of writing by gathering relevant data (i.e. statistics) through critical studies, systematic review of literature and meta-analysis on the theme.

\section{Conclusion}

Renewable energies are expected to play a key role in the coming years in the search for cleaner energy and security of supply. However, its success will continue to depend on State support, changes in the electricity sector and competition from rival energy sources. States have different mechanisms to guide agents, but at a cost that must be balanced with the revenue or the benefit. Both the EU-27 and the Portuguese strategy do not aim to improve energy efficiency, in addition to optimizing energy consumption. The findings are validated by an objective analysis.

\section{Conflicts of Interest}

The authors declare no conflicts of interest regarding the publication of this paper.

\section{References}

DGEG (2019a). A facturaenergéticaportuguesa.

DGEG (2019b). Renováveis-Estatísticasrápidas, Novembro.

Earth Track (2019a). https://www.earthtrack.net/

Earth Track (2019b). http://www.earthtrack.net/earthtrack/library/EgySubsTopTen.pdf

European Commission (2019). Portugal's Energy Factsheet, Directorate General for Energy. Brussels.

European Commission Statistics, Eurostat (2019a). https://ec.europa.eu/eurostat/statistics-explained/index.php/Electricity_production,_co nsumption_and_market_overview\#Electricity_generation

European Commission Statistics, Eurostat (2019b). 
https://ec.europa.eu/eurostat/cache/infographs/energy/bloc-2c.html

European Environment Agency, Copenhagen (2004). Energy Subsidies in the European Union: A Brief Overview.

Fiscally Green Canada (2019). http://www.fiscallygreen.ca/efr5.html

International Institute of Economics (2019).

http://www.iie.com/publications/chapters_preview/37/4iie2504.pdf

OECD Workshop on Environmentally Harmful Subsidies (2019).

http://www1.oecd.org/agr/ehsw/summary_and_conclusions.PDF

PortáteisnaHora (2019). http://www.renovaveisnahora.pt

The Earth Council (2019). https://earthcouncilalliance.org/

Unfair Aid: The Subsidies Keeping Nuclear Energy Afloat, World Information Service on Energy (WISE) \& Nuclear Information and Resource Service (NIRS) (2005).

http://www10.antenna.nl/wise/630-31/630-31.pdf

US Department of Commerce (2019). https://www.commerce.gov/

WTO (2019a). Agreement on Subsidies and Countervailing Measures ("SCM Agreement"). http://www.wto.org/english/tratop_e/scm_e/subs_e.htm

WTO (2019b). Agreement on Subsidies and Countervailing Measures.

http://www.wto.org/english/docs_e/legal_e/24-scm_01_e.htm 